\title{
Josef Bayer
}

\section{Doubly-Filled Comp, wh head-movement, and derivational economy}

\section{Introduction}

Bavarian and Alemannic are South-German dialects in which the Doubly-Filled Comp Filter (DFCF ${ }^{1}$ seems to be suspended. As some traditional as well as some recent empirical work has shown, however, this is not true in general. While uncontroversially phrasal wh-operators tend to require an overt complementizer, pure wh-words tend to reject it.

The data are distributed roughly as follows:

(1) [CP wh-phrase $[\mathrm{C}, \mathrm{C}[\ldots]]]$

(2) $\star[C P$ wh-word $[C, C[\ldots]]]$

(3) $[\mathrm{CP}$ wh-word $[\mathrm{C}, \emptyset[\ldots]]]$

In this contribution, it will be argued (i) that this distribution is not the result of an accidental spell-out convention, and (ii) that (3) is more successfully analyzed as in (4).

(4) $[\mathrm{CP}[\mathrm{C}$ wh-word $][\ldots]]$

In other words, it will be argued that it makes a difference whether a wh-word or a wh-phrase undergoes movement, and that the former case may be analyzed as head-movement. In this case, the wh-element is simultaneously a complementizer. As a consequence, merger of a separate complementizer is superfluous and therefore forbidden. The article is organized as follows: After presentation of the core data in 2., it will be shown in 3. under which circumstances the wh-operator may move "head-style". Head-movement will be shown in section 4 to be a preferred option because phrase structure can be extended on the sole basis of internal merger. The account will be supported in section 5

1 The term is kept although it dates back to a time in which S" was thought to dominate two complementizer positions. In the present article, we start out from the later assumption of a functional category $\mathrm{C}$ which projects a $\mathrm{CP}$ such that $\mathrm{C}$ can host a complementizer and SpecCP, a featurally matching specifier. 
with novel data from cliticization to the C-position and complementizer inflection. Section 6 contains a short note on diachrony and cross-linguistic variation. Section 7 gives a sketch of how data from sluicing can be captured. Section 8 presents a note on chain uniformity. A conclusion follows in section 9.

\section{DFC and DFCF in South German dialects with special emphasis on Bavarian}

The DFCF dates back to Chomsky \& Lasnik (1977). It says essentially what (5) expresses.

(5) ${ }^{\star}[\alpha \beta]$, if $\alpha$ is in SpecCP and $\beta$ in the C-Position of the same CP, and $\alpha$ and $\beta$ are overt.

This filter holds for many standard languages but may be the result of normative rules which often had no effect in older stages of a language, and which have no effect in many colloquial styles and dialects. Bavarian and Alemannic allow so-called "doubly-filled Comp" (DFC). The following examples show that in modern German, where it is stigmatized, DFC can be found even in the written language.

(6) Ich habe mein Handy immer an die Boxen gehalten und 10 I have my cell phone always at the boxes held and 10 Sekunden später wusste ich, von wem dass der Song seconds later knew I from whom that the song wirklich ist. really is. 'I held my cell phone always to the speakers and after 10 seconds, I knew from whom the song really is.'

http://hitparade.ch/interview.asp?id=55 [written German from Switzerland]

(7) dann musst $d u$ dich ernsthaft fragen, von wem dass $d u$ then must you REF seriously ask from whom that you etwas willst. something want.

'Then you have to seriously ask yourself who you want something from' http://forum.gofeminin.de/forum/teenfilles/_f3347_teenfilles-Mein-Freindverdammt-hubsch-und-der-Typ-fur-den-mein-Herzschlagt-hasslich.html 
In previous generative work, DFC was taken to be an unconditional option in these dialects (Bayer 1984). However, traditional dialect grammars report that DFC virtually never occurs with was ('what') and wer ('who'), (Schiepek 1899; Merkle 1984; Noth 1993; Steininger 1994). Within their generative studies of Bernese Swiss German, Penner and Bader (1995) and within his generative study of Bavarian, Weiß $(1998$; 2004) point respectively to a correlation between the size of the wh-Operator and the presence or absence of a complementizer. Schönenberger (2006) finds in a corpus study of Swiss German from Lucerne and St. Gallen that dass occurs almost never in the context of monosyllabic wh-words while it appears with 50\% certainty in the context of bi-syllabic whwords in Lucerne German and becomes close to obligatory in St.Gallen German. With genuine wh-phrases like an was für Leute ('to what kind of people') dass tends to be obligatory.

Since the following discussion will focus mainly on Bavarian, it is important to have empirically reliable information about the occurrence of DFC in this dialect. Judgment studies were carried out with Bavarian speakers from different regions and age/education groups. The task was to value spoken sentences according to the six-point scale of the German school grades according to which $1=$ best and 6 = worst. $^{2}$

Table 1: 10 speakers of Middle Bavarian, age: $40-78$, lower educational background; 12 sentences with wh-words; 12 sentences with wh-phrases.

\begin{tabular}{lll}
\hline & $\begin{array}{l}\text { WITHOUT } \\
\text { COMPLEMENTIZER }\end{array}$ & $\begin{array}{l}\text { WITH } \\
\text { COMPLEMENTIZER }\end{array}$ \\
\hline was ('what') & 1 & 3,5 \\
wie ('how', 'as') etc. & 1,1 & 3,6 \\
wem ('who-DAT') & 1,1 & 2,5 \\
warum ('why') & 1,25 & 1,25 \\
P+wh-word, e.g. with what & 1,1 & 1,25 \\
P+wh-phrase, e.g. which NP & 1,3 & 1,5 \\
\hline
\end{tabular}

Some speakers had a tendency to shy away from giving bad grades; nevertheless, was and wie are the worst in combination with the complementizer dass; wem and warum are intermediary. A similar task was given to younger dialect speakers with university education and to younger speakers with mixed educational backgrounds.

2 Speakers were instructed that 1 means "I could perfectly use this sentence in my own dialect", whereas 6 means "I could never use this sentence in my own dialect". 
Table 2: 3 speakers of Middle to Eastern Bavarian, age: 25-35, university education.

\begin{tabular}{lll}
\hline & WITHOUT & WITH \\
& COMPLEMENTIZER & COMPLEMENTIZER \\
\hline was ('what') & 1,3 & 5,7 \\
wer ('who-NOM') & 1 & 4,9 \\
wo ('where') & 1 & 5 \\
wem ('who-DAT') & 1,2 & 3,9 \\
P+wh-word & 1 & 1,9 \\
\hline
\end{tabular}

These speakers were more ready to give bad grades. The results are sharper. The wh-words was, wer and wo are inacceptable with dass. Again, wem has a somewhat intermediate status.

Table 3: 13 young speakers from Regen (Middle to Eastern Bavarian), mixed educational backgrounds.

\begin{tabular}{lll}
\hline & WITHOUT & WITH \\
& COMPLEMENTIZER & COMPLEMENTIZER \\
\hline was ('what') & 1.5 & 4.6 \\
wer ('who-NOM') & 1.3 & 4.7 \\
wo ('where') & 1.6 & 4.5 \\
wem ('who-DAT') & 2.2 & 4.4 \\
P+wh-word & 1.5 & 2 \\
\hline
\end{tabular}

The dative pronoun wem cannot be distinguished in this group. Nevertheless, the main effect of wh-word versus wh-phrase remains as stable as in the other investigations.

The intermediate status of the wh-words warum and wem can be explained if it is realized that they involve more structure than simplex wh-pronouns. For warum this is obvious because it is bi-morphemic and involves the preposition um. The wh-part is a so-called "R-pronoun" as familiar from discussions of Dutch syntax. According to the structure in (8), warum is underlyingly a PP, although it is a phonological word in terms of phonology.

(8) $\left[\mathrm{PP}\right.$ wa(s) $+\left[{ }_{\mathrm{P}}\right.$, um was $\left.]\right]$

what for

According to Bayer, Bader \& Meng (2001), the dative pronoun wem is likewise more complex than a nominative or accusative pronoun. The latter two can be morphologically primitive as shown by the syncretic form was; the dative, however, must be overtly Case-marked. Consider the contrast in (9). 
(9) a. Welch-em Vorschlag hast $d u$ widersprochen? which-DAT proposal have you objected 'Which proposal did you object to?'

b. *Was hast du widersprochen? what have you objected 'What did you object to?'

Bayer, Bader and Meng (2001) propose the underlying structure in (10) by which dative Case is syntactically represented as the head of a Kase phrase (KP). ${ }^{3}$

(10) $\left[\mathrm{KP} \mathrm{K}^{\circ}[\mathrm{NP}\right.$ wem] $]$

If this is so, there is a reason why speakers fluctuate between a PF-based wordsize and a syntax-based phrase structural parse of these wh-items. Given this, the proper generalization is as in (11).

(11) Descriptive generalization

The "size" of the wh-operator determines whether wh can combine with a complementizer or not. Full-fledged wh-phrases can combine with a complementizer; word-size wh must not combine with a complementizer. ${ }^{4}$

As pointed out by a reviewer, (11) could be misunderstood as a plea for direct influence of phonological weight on syntactic structure and therefore as a determination that would disallow any variation. I will address this issue at the end of section 4 .

\section{Wh-movement as head-movement}

What can explain the distribution of the data as described in (11)? Bayer and Brandner (2008a, 2008b) propose that in Alemannic and in Bavarian DFC-

3 For the motivation of KP in German see Bayer, Bader and Meng (2001); for KP in general see Bittner and Hale (1996). As shown in detail by Seiler (2003), the dative is frequently found in southern German dialects to be "strengthened" by a preposition. One can see this preposition as the spell-out of $\mathrm{K}$.

4 Interestingly, close parallels have been found in V2 and suspended V2 in Northern Norwegian dialects; see Vangsnes (2005); Westergaard and Vansgnes (2005), and the discussion in Bayer and Brandner (2008a). 
dialects the complementizer must be absent if the wh-word itself is the complementizer. If the wh-lexeme itself is a complementizer, merger of a separate complementizer would be superfluous and is therefore banned by economy. Bayer and Brandner suggest a latent categorial feature $C$ on wh-words which is activated under appropriate contextual conditions.

\section{(12) Latent C-feature}

Wh-items may possess a latent $\mathrm{C}$-feature $\alpha \mathrm{C}$. If $\alpha$ can be set to + , the wh-item is simultaneously $C$ and will project a CP. If $\alpha$ is set to - , the C-feature will delete.

The assumed feature structure of wh-lexemes is as in (13).

(13) Feature structure for simplex wh-lexemes $\mathrm{X}[\mathrm{wh}, \ldots, \alpha \mathrm{C}]$.

$\alpha \mathrm{C}$ can only turn into $+\mathrm{C}$ if $\mathrm{X}$ is merged with TP. If $\mathrm{X}$ is trapped in some branching structure, it cannot become a sister of TP. In that case, $\alpha \mathrm{C}$ will turn to $-\mathrm{C}$ and will ultimately delete. Let us first consider the beginning of a derivation. In (14), wh is merged with $\mathrm{V}$.

(14)

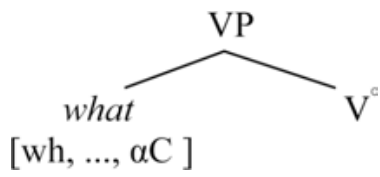

Although wh is merged with $\mathrm{V}^{\circ}$ and is therefore in this context a wh XP, its projective status as such remains formally ambiguous between head and phrase. If wh is re-merged with TP, its latent feature $\alpha \mathrm{C}$ will be set to $+\mathrm{C}$ and will project a CP as shown in (15).

(15)

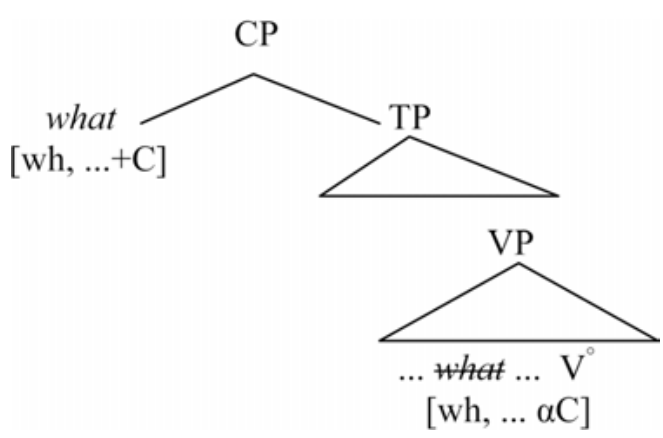


What being a potential head, the CP in (15) does not result from external merger of $\mathrm{C}$ but importantly from internal merger of the wh-word. We assume that internal merger results from the possibility of $C$ to be merged with TP and is as such not feature-driven. $C$ does not come alone but in combination with a wh-feature. This amounts to saying that the projection of a wh-CP results from "self-attachment" rather than from merger of a $\mathrm{C}$ which contains an unvalued feature $u$ Wh that attracts a wh-phrase. ${ }^{5}$ As Fanselow (2004: 26) puts it, "the head in question possesses the checking feature and the feature to be checked at the same time."

Merger of what with an NP as in (16) does not do any damage because what fails to become a sister of TP and will therefore never activate the C-feature.

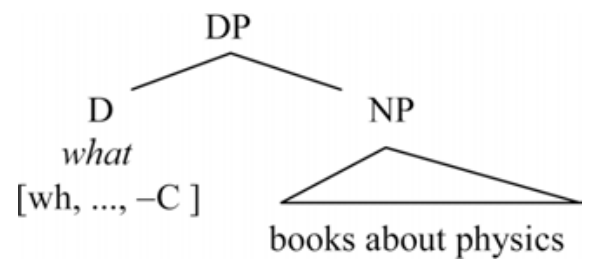

A wh-DP as in (16) will move to the specifier of an independently merged C. In a DFC-language like Bavarian, this $C$ is normally overt, and we observe the DFCphenomenon, e.g. in an embedded sentence such as (17).

I mechat wissn, [CP [wäichas Physikbuach] $\left[{ }_{C}\right.$, dass $\left[_{T P}\right.$ d'Sophie
I want know which physics-book that the-Sophie
g'lesn hot]]]
read has
'I'd like to know which physics book Sophie has read.'

In generative grammar, the proposal of wh-movement as head-movement clearly invokes various questions. The GB-version of X-bar theory that has adopted functional categories suggests a clear division of heads and specifiers. However, Bare Phrase Structure (BPS) as suggested in Chomsky (1995) and following work,

5 Movement of the complementizer has been suggested for independent reasons in the T-to- $\mathrm{C}$ movement account of Pesetsky and Torrego (2001). Self-attachment of the verb to its own projection has been explicitly proposed by Platzack (1996), Koeneman (2000; 2002), Bury (2002), Fanselow (2002a), Surányi (2003), Brandner (2004) and van Craenenbroek (2006). Donati (2006) assumes wh-head-movement for independent reasons. It has been implicitly assumed by many more. For a comprehensive overview and detailed theoretical discussion see Georgi and Müller (2010). 
does not and cannot insist on a pre-established division. In BPS, the decision of what is a head and what is a complement or a specifier is made in the course of the derivation. Under the realistic assumption that a lexical item may embrace more than a single feature, we end up with the possibility of a complex feature structure as indicated in (13). One lexical item may simultaneously embrace the feature of $\mathrm{C}$ and the feature of wh, the latter of which may still prove to be decomposable as we will argue below. ${ }^{6}$ It seems that for the purpose of syntactic activation, the features on a lexical item must somehow be ordered. I will turn to this question in the next section.

\section{Economy $^{7}$}

Head-movement has been a controversial issue in minimalist syntax over the last few years. Chomsky (2001) argued that it might be an artifact that can be eliminated from the theory. ${ }^{8}$ In the meantime, head-movement is back on stage. Chomsky (2010) suggests that, contrary to earlier assumptions, move (= internal merge) may even be preferred over merge (= external merge) because it partially circumvents the notorious numeration problem and thus narrows the search space from which a new lexical item can be drawn for further computation. For the concrete case of DFC in Bavarian, the decision is between (18a) and (18b).
a. [CP wh [C, comp [TP ... wh ...]]]
$>$ external merger of comp
$>$ internal merger of wh
b. [CР wh $[$ TР ... wh ...]]
$>$ internal merger of wh (= comp)

\footnotetext{
6 Although the present chapter does not focus on general issues of lexicon and morphology design, it should not be overlooked that there is a clear affinity to the program of Nano-Syntax (NS) as envisaged by Starke (2009) and publications quoted there. In NS, syntax projects from single features building morphemes and phrase structure alike. Thus, a lexical item - as defined by phonology - may associate with a syntactic phrase. The possibility of a combination of features which otherwise often distribute in phrase structure over comp (C) and wh (SpecCP) is expected from this perspective.

7 Thanks to Joe Emonds for his suggestions about this part.

8 The argument was placed in the larger question about movement as such. Movement was seen as an "imperfection" in the design of language. Head-movement was seen as movement that falls outside core syntax, essentially a PF-operation. In the aftermath of Chomsky's argumentation, Müller (2004) went as far as suggesting reanalysis of a classical and so far undisputed case of head movement, namely Germanic V2, as phrasal movement in disguise (remnant VPmovement).
} 
If the derivations underlying both structures achieve the same result at LF, (18b) should be preferred over (18a) under minimalist assumptions. (18b) clearly involves fewer computational steps and ergo less structure than (18a). The background assumption of this is, of course, the standard distinction between features and categories. In (18a) the computational system must access the lexicon twice whereas in (18b) it must access the lexicon only once. If we assume that the internal feature structure of the wh-item is the same, (18a) tolerates a redundancy. Comp is merged although it could be activated via the featural make-up of the wh-lexeme. In that case, the feature $\alpha \mathrm{C}$ is superfluous and must be deleted. We will shortly see that a wh-element may involve yet another feature. If this is so, the process of external merger will need to be iterated, thus amplifying the economy gap between the two derivations. In (18b), the wh-element is a potential head and involves the sub feature $\alpha \mathrm{C}$. Therefore, it can be "recycled" in a single-step operation of movement. I will shortly turn to a slight modification of this. ${ }^{9}$

Being primarily concerned with a formal account of grammaticalization, van Gelderen (2004:10) proposes the general economy principle in (19):

\section{(19) Head Preference or Spec to Head Principle}

Be a head rather than a phrase!

Given that (18b) conforms to (19), and the lexical entry of the wh-item embraces $\alpha \mathrm{C}$ as a sub feature, external merger of comp will be blocked, and the derivation underlying (18a) will be discarded. Sentences like in (20), taken from one of the empirical investigations, which native speakers of Bavarian overwhelmingly reject and would never produce spontaneously, can be derived but are excluded by economy.

(20) a. *I woass aa ned, wos dass bei de Nachban wieder lous gwen is I know also not what that at the neighbors again on been has 'I also don't know what has been going on at our neighbors'

b. *I mechat wissn, wia dass-a dees iwerlebt hod

I want know how that-he this survived has

'I'd like to know how he survived that'

In each case, there is a less costly derivation.

9 I am aware that the space which I can reserve here for the issue of derivational economy is far too small to cope with the problem. See Sternefeld (1997) for detailed discussion. 
Bavarian stands in an interesting contrast with colloquial (substandard) Dutch (E. Hoekstra 1993; Barbiers et al. 2005), Frisian (de Haan and Weerman 1986; Reuland 1990), and West-Flemish (Haegeman 1992), varieties in which the left edge of CP appears to be more articulate than in Standard Dutch. The following Dutch data from E. Hoekstra (1993) show in (21a) complementizer doubling and in (21b) wh-movement on top of complementizer doubling.

(21) a. Ik vraag me af [of [dat [Ajax de volgende ronde haalt]]] I ask me PRT if that Ajax the next round reaches 'I wonder whether Ajax [= the Amsterdam football team] will make it to the next round'

b. Ze weet [wie [of [dat [hij had willen opbellen]]]] she knows who if that he had wanted call 'She knows who he wanted to call up'

While in Standard German as well as in Standard Dutch, the respective interrogative complementizers $o b$ and of serve simultaneously as polar interrogative markers (typing particles) and as subordinators, the variety of Dutch seen in (21a) spells out the features of polarity (of) and subordination (dat) with two syntactic heads. In (21b), there is even a tripartite structure in which one could argue that the wh-operator has been moved to the specifier of the interrogative head of. ${ }^{10}$ The syntactic structure is as in (22).

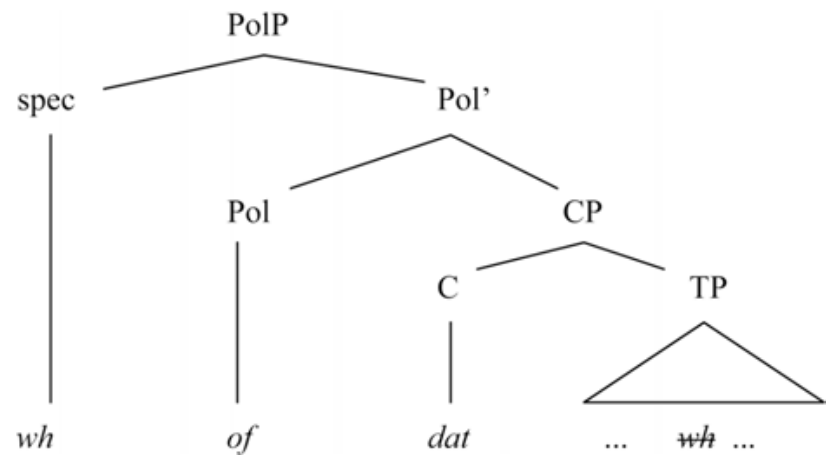

10 As I point out in Bayer (2006), this division cannot be accidental. It maps rather directly onto the semantic structure of embedded wh-questions for which the partition approach to questions (cf. Groenendijk and Stokhof 1982; Higginbotham 1993, 1997; Lahiri 2002) has argued independently. Wh-questions are like polar (or disjunctive) questions with the difference that they have a gap. John knows whether Bill smiled is true iff John knows that Bill smiled or that Bill did not smile. John knows who smiled is true iff John knows for each individual $\mathrm{x}$ (that may be a contextually relevant potential smiler) that $\mathrm{x}$ smiled or $\mathrm{x}$ did not smile. 
Expanding the proposal in Bayer and Brandner (2008a,b), assume that in Bavarian a word-size wh-lexeme embraces a C-feature which - by virtue of being interrogative - covers also polarity, it is easy to see how virtually the same representation as in (22) can be built solely on the basis of internal merge. Let us suggest here that the feature structure of a wh-item is slightly more complex than in (13), namely as in (23) below. As Georgi and Müller (2010) point out, features on a head must be ordered. In order for the wh-word to be a successful complementizer, the C-feature must be visible. According to Georgi and Müller, it is visible if it is the topmost feature on a stack and will be removed as soon as the head has been re-merged with TP. Adding the feature Pol immediately below $\mathrm{C}$ enable the head to undergo re-merged with the C-headed CP. Adding the feature wh immediately below Pol will enable the head to be re-merged with PolP. Let us then revise (13) as in (23) in which features are represented as an ordered feature set; $a \prec b$ should be understood as “a precedes b".

(23) Feature structure for simplex wh-lexemes (revised)

$$
\mathrm{X}\{\alpha \mathrm{C} \prec \beta \mathrm{Pol} \prec y w h \prec \ldots\}^{11}
$$

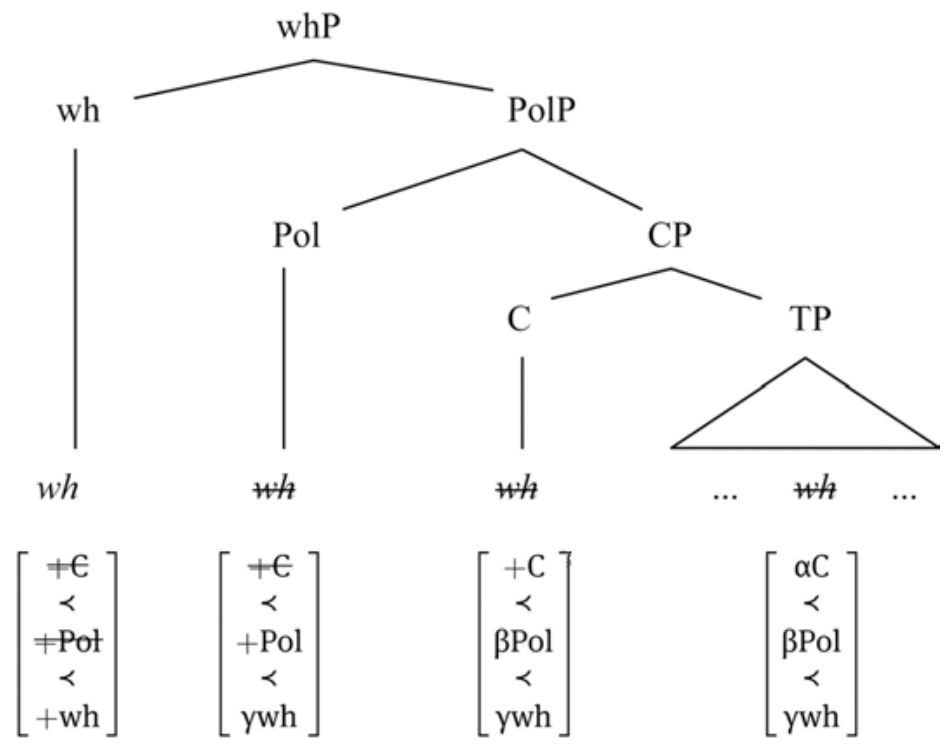

11 Simplifying somewhat, I assume here that Pol is a subfeature of wh and can be set to + or -. Notice that in German as in various other languages there is lexical ambiguity between an interrogative and an indefinite reading. If there is no interrogative force in the left clausal periphery, 
In (24), the word-size wh-element re-attaches to TP activating $\mathrm{C}$, then re-attaches to $\mathrm{CP}$ activating PolP and finally re-attaches to PolP to activate the WhP. In this way, the feature structure of the lexical item that must be assumed for independent reasons unfolds automatically in the process of merger. The process underlying this derivation is a process of "recycling" which is repeated until all the features in the feature configuration are either activated or deleted from the derivation. Deletion can apply only if the feature is set to minus or is deactivated due to semantic interpretation. ${ }^{12}$

As an intermediary conclusion, it should be clear at this point that wh headmovement is a viable option within the Minimalist Program and especially within the assumptions of BPS. A derivation in terms of re-attachment of a potential syntactic head leads to a more economical derivation than the (coexisting) mechanism of external merger of a new functional head and subsequent attraction for the purpose of feature valuation. One attractive aspect of this approach is that it can capture syntactic variation in an insightful and nonstipulative way. The source of variation rests in lexical differences (cf. Borer 1984). If syntactic differences between related varieties of Germanic such as Bavarian and Dutch, Flemish, Frisian etc. can be traced back to differences in lexical feature structure, such a result seems to be desirable as it would fall into largely understood territory. Lexical differences can, however, also be found within one dialect and even within one idiolect. Thus, it should not be surprising to observe intra-dialectal or even intra-idiolectal variation in the domain of DFC. As one reviewer points out, one can easily find examples of wer dass and even was dass, i.e. of the least favored combinations. Weiß (2004) argues that the DFC-variation can hardly be rooted in core grammar in the sense that a "heavier" constituent would have "more features". He attributes the distribution

wh-pronouns in situ receive an indefinite interpretation. In this case, $\beta$ Pol would be turned into -Pol and get deleted from the structure.
(i) Ich habe was gesehen
I have wh-thing seen
'I saw something'

Notice that the system of Georgi and Müller is more complex because it adds to their structure-building (subcategorization/merge) feature $\left[\bullet \mathrm{F} \bullet\right.$ ] also a probe/agree feature $\left[k_{k} \mathrm{~F} * \mathbb{k}\right]$ that may operate asynchronically in the derivation. For reasons of space I will not elaborate here on this aspect of head-reprojection.

12 Of course, it is not a trivial issue to determine at which point of a derivation a feature is deactivated. Nevertheless it should be clear for the core cases of scope taking $\mathrm{C}$ becomes irrelevant after it has been merged with TP; Pol becomes irrelevant after it has been merged with CP; Wh becomes irrelevant after it has been merged with PolP and has been subject to "scope freezing" (cf. Baker 1970 and following work). 
of the data to requirements of the processing system, in particular to the need of quick identification of the clause type by virtue of the complementizer. While I agree that the covariation of phonological weight and number of features is likely to be illusory, I also feel that his explanation should be met with reservation. First it is unclear in which sense the processing system could benefit from early identification of the clause type. ${ }^{13}$ Secondly it is unclear why a heavy whphrase following a question-embedding verb would qualify as an identifier less successfully than a wh-word. I find it far more plausible to acknowledge that was is the most underspecified wh-element of the German lexicon and as such the top candidate in adopting additional features without running into conflicts, and that there are other wh-lexemes which can do so to a higher or lower degree, and that this variation may be a matter of the individual mental lexicon.

By looking at some familiar morphosyntactic processes, the next section will provide independent motivation for the correctness of wh head raising and the approach as it has been developed so far.

\section{Cliticization and comp-inflection}

Unlike Standard German, which may have only strong and weak pronouns (see Cardinaletti, 1999), the South German dialects undoubtedly have clitics. In Bavarian, the only way to express the German examples in (25) would be as in (26).

a. Wo hat er es dir denn hingelegt
where has he $\mathrm{N}_{\mathrm{NOM}} \mathrm{it}_{\mathrm{ACC}}$ you $\mathrm{DAT}_{\mathrm{DAT}}$ PRT down-put
'Where did he leave it for you'
b. Ich meine, dass er es dir hingelegt hat I think that he NOM $_{\text {ACC }}$ you $_{\text {DAT }}$ down-put has 'I think that he has left it for you'

13 In German, sentences with a V2-complement like (i) are known to hardly create parsing difficulties although there is a firm local ambiguity as shown in (ii).

(i) Ich glaube an meine Theorie kann sich niemand mehr erinnern I believe in my theory can REF nobody PART remember 'I believe nobody can remember my theory'

(ii) Ich glaube an meine Theorie...

'I believe in my (own) theory'

For lucid theoretical discussion see Gorrell (1994; 1995). 
(26) a. Wou hod-a $-\boldsymbol{s} \quad-\boldsymbol{d a} \quad \boldsymbol{n} \quad$ hĩ:g'legt? where had-he NOM- it $_{\text {ACC }}-\mathrm{you}_{\mathrm{DAT}}-\mathrm{PRT}$ down-put

$\begin{array}{lllll}\text { b. I moan dass-a }-\boldsymbol{s} \quad-\boldsymbol{d a} & \text { hĩ:g'legt hod } \\ \text { I think that-he } \mathrm{NOM}_{\mathrm{NO}}-\mathrm{it}_{\mathrm{ACC}}-\mathrm{you}_{\mathrm{DAT}} & \text { down-put has }\end{array}$

The clitics attach in (26a) to the finite verb which is in the position of $\mathrm{C}$, the so-called "Wackernagel" position. Their distribution is the same when they cliticize to a complementizer as in (26b). ${ }^{14}$ As an extension of cliticization, Bavarian also shows in more limited cases what has become known as comp-inflection. ${ }^{15}$ In this case, a clitic has been reanalyzed as an inflectional suffix, which appears obligatorily on the complementizer. The full pronoun can still follow as seen in (27).

(27) Wenn-st (du) ned foig -st nou schbi:r-a-de ei if -2SG (you) not obey -2SG then lock -I -you up 'If you don't listen to me, I'll lock you up'

There may be the impression that Bavarian has clitic-doubling. However, doubling is confined to 2nd person singular and plural (and in some dialects also 1st person plural) although there is a pervasive clitic paradigm. There is nothing like clitic doubling for 1st person singular ( ${ }^{\star}$ wenn-e $\boldsymbol{i}$ : ned foig, if-I I not obey) or 3rd person ( ${ }^{\star}$ wenn-a er ned foigt, if-he he not obeys). Thus, the 2nd person clitics must at some stage have been reanalyzed as inflectional suffixes. In the mind of a current speaker, they are inflectional.

I would now like to demonstrate that external sandhi, consonantal epenthesis and comp-inflection prove consistently that word size wh-elements behave like complementizers, i.e. are like heads resembling the functional head $\mathrm{C}$, and not like syntactic phrases.

\subsection{External sandhi: Underlying / $\mathrm{r} /$}

In Bavarian, like in many varieties of spoken German, $/ \mathrm{r} /$ is consonantal in the onset of a syllable but vocalized in the rhyme (Wiese 1996). Consider the wh-pronoun wer, [vee] ('who'). Cliticization crosses a weak prosodic boundary and induces onset maximization. In this case, $/ \mathrm{r} /$ will be pronounced as seen in (28b).

14 The clitic particle $-n$ is absent in (26b) as it applies only to questions.

15 Pfalz (1918); Altmann (1984); Bayer (1984); Weiß (1998, 2005); Fuß (2005) among others. 
(28)

a. De woass, wea-s is
she knows who-it/she is
'She knows who it/she is'

b. De woass, we $-\boldsymbol{r}-e$ bin

she knows who-R-I am

'She knows who I am'

The relevant foot structure in (28b) is $\left[{ }_{\varphi}[\sigma \mathrm{v} v e]\left[{ }_{\sigma}\right.\right.$ re $\left.]\right]$. Take now for comparison a bona fide wh-phrase that ends in a vocalized / $\mathrm{r} /$ as in Uhr, [ue] ('clock'). Cliticization to such a phrase leads to a bad result as (29a) shows. One way out could be the avoidance of cliticization as in (29b). The preferred way would be to merge the complementizer dass and thus have a proper host for cliticization ready as in (29c).
a. ${ }^{\star D e}$ woass [um wiavui Uh $\left.-\mathrm{r}\right]-e$ geh
she knows at how-much clock-R-I go
'She knows at what time I leave'
b. De woass [um wiavui Ua] $i$ : geh
she knows at how-much clock I go
c. De woass $\left[\begin{array}{ll}\text { um wiavui } U a\end{array}\right]$ dass-e geh she knows at how-much clock that -I go

These data suggest that dass and wer behave alike. Both serve as hosts for cliticization. Genuine wh-phrases such as um wieviel Uhr are flanked with strong prosodic boundaries and show very distinct behavior. These facts are straightforwardly reconciled with the syntactic derivation proposed above according to which a word-size wh-element is internally merged with TP. They can hardly be reconciled with a conventional X-bar theoretic derivation in which an empty complementizer is merged to $\mathrm{TP}$, and the wh-element moves to its specifier. ${ }^{16}$ The same is true for derivations in which the wh-phrase lands in a distinct higher CP-shell as suggested by Baltin (2008) or by Koopman's (2000) “Generalized Doubly-Filled Comp Filter", which bans lexical material in both the head and spec of a given projection. These accounts are by definition blind to the size or

\footnotetext{
16 The case is reminiscent of wanna-contraction. It has been argued that to cannot cliticize onto want across an intervening trace. This blocks * Who do you wanna die? If this reasoning holds water, cliticization across an empty complementizer should likewise be impossible, contrary to what (28b) shows to be actually the case.
} 
the shape of the wh-operator that move to the left periphery. Some complex machinery with a number of special assumptions would be required to accommodate the Bavarian cliticization data in such a theory.

\subsection{Consonantal epenthesis}

Consider next lexical elements which terminate in a diphthong that targets the vowel [e]. In Bavarian, these diphthongs embrace [ie] and [ue]. Attachment of a vocalic clitic to such elements triggers consonantal epenthesis for the avoidance of hiatus. ${ }^{17}$ In Bavarian, the epenthetic element is $[r]$ as seen in (30b).
a. wia-s hinte schaut sicht-s an Sepp as -she back looks sees-she the Sepp
'As she looks back, she sees Sepp'
b. wia-r-e hinte schau sich-e an Sepp as -R-I back looks see-I the Sepp 'As I look back, I see Sepp'

The underlying form of the clitic's host is wie, phonetically [vie]; $r$ is not part of it. Thus, it must be an intrusive element. Interestingly, epenthesis is unattested (and unacceptable) if the host is part of a genuine syntactic phrase. Consider the host Schuh, [Jue] ('shoe' or 'shoes').
a. ${ }^{\star}$ Sog-ma [wos fia Schua]-r-e õ:ziang soi tell-me what for shoes -R -I on-put should 'Tell me which shoes I should put on'
b. Sog-ma [wos fia Schua] dass-e õ:ziang soi tell-me what for shoes that-I on-put should

The restriction is the same as in (29). Cliticization applies to a syntactic head but cannot apply to a wh-phrase. In the presence of a wh-phrase such as wos fia Schua, a functional head, namely dass, is inserted, and consonantal epenthesis does not emerge. ${ }^{18}$ Thus, data from consonantal epenthesis show again that this process is limited to the environment of a functional head, and that word-size wh-operators behave like such heads whereas genuine wh-phrases do not.

17 Cf. Gutch (1992) for detailed discussion.

18 Alemannic uses $n$ for epenthesis. As Ortmann (1998) shows on the basis of data from the Black Forest area, $n$ is epenthesized for hiatus avoidance in cliticizations to the functional 


\subsection{Comp inflection}

Consider finally comp-inflection for 2nd person sg. and pl. In Bayer (1984), I suggested that inflectional suffixes can target not only heads but also phrases. This suggestion is likely to be wrong. ${ }^{19}$ Importantly, comp-inflection is completely well-formed on wh-words.

a. I woass scho, wia-st (du) ausschau-st

I know already how-2SG you out-look-2SG

'I already know what you(sg) look like'

b. I woass scho, wann-ts (e:s) in-s Bett geh-ts

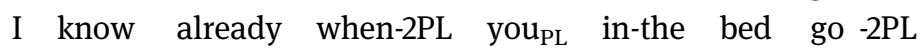

'I already know when you(pl) go to bed'

Comp-inflection on wh-phrases is dispreferred or downright ungrammatical. In the following examples, there is a strong grammaticality difference between (a) and (b).

(33) a. ${ }^{\star} I$ woass scho, wos fia Schua-st (du) õ:zong ho -st

I know already what for shoes-2SG you on-put have-2SG

'I already know what kind of shoes you have put on'

b. I woass scho, wos fia Schua dass-st (du) õ:zong ho -st

I know already what for shoes that-2SG you on-put have-2SG

heads C and P. Consider the word-size wh-element wo, [vo:] ('where') versus a comparable open class noun that is part of a genuine wh-phrase:

(i) I weiss it, wo -n-er ani isch

I know not where-N-he towards is

'I don't know where he went'

(ii) a. ${ }^{\star} I$ weiß it $[u f$ wellem Klo] $-\boldsymbol{n}$-i ga hocke

I know not on which toilet-N-I go sit

'I don't know on which toilet I will sit'

b. I weiß it [uf wellem Klo] dass-i ga hocke

I know not on which toilet that-I go sit

19 Relevant criticism had already been formulated by Marina Nespor (p.c.) at the time of publication of Bayer (1984). At that early stage of GB-theory, the dilemma could not be resolved. 

a. ${ }^{\star} I$ woass scho
wia oft -ts
(e:s) g'fäit
hab -ts

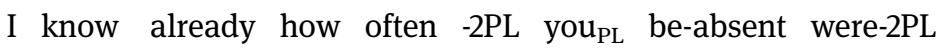

'I already know how often you(pl) have been absent'
b. I woass scho,
wia oft
dass-ts
(e:s) g'fäit
hab -ts
I know already
how often
that-2PL you $_{\mathrm{PL}}$
be-absent
were-2PL

In the context of a wh-operator which cannot be analyzed as a potential head, comp inflection fails, and the complementizer dass has to be externally merged. 20

Unfortunately, grammaticality judgments are often less than crystal clear and may be contaminated by Standard German. One cannot exclude the possibility that speakers accept structures as in (33a) and (34a) by virtue of an analogical generalization by which 2nd person inflection is associated not with the host as such but rather with the linear position. To control for that, a production experiment was carried out in which native speakers of Bavarian were

20 A caveat must be added about PPs. It seems that for many speakers there is the possibility to inflect a simplex wh-item such as was even though it is part of a PP. Dialect speakers write on the internet in their dialect, e.g

(i) nix verbotenes, und a ned des [an wo] - st du schon nothing forbidden and also not this at what -2SG you already

wieder denk -st

again think - 2SG

'Nothing forbidden and not what you already have thoughts about'

http://www.flf-book.de/Benutzer/Partybus.240.htm

I tend to say that PP is a potential extension of the category in its complement. If the complement is $\mathrm{X}^{\circ}, \mathrm{P}+\mathrm{X}^{\circ}$ is also an $\mathrm{X}^{\circ}$. Evidence for this comes from the copying strategy in wh-scope extension that is possible in various German dialects.

(ii) Wo glaubst du, wo er wohnt?

where believe you where he lives

'Where do you believe he lives?'

Significantly, no copying of genuine XPs is ever possible, - with the exception of PPs of type $\mathrm{P}+\mathrm{X}^{\circ}$.

(iii) a. [Mit wem] glaubst du, [mit wem] wir uns treffen könnten? with who believe you with who we REFL meet could 'Who do you believe we could meet with?'

b. *[Mit welchen Linguisten] glaubst du, [mit welchen Linguisten] wir uns treffen könnten? 'Which linguist do you believe we could meet with?'

See Bayer and Bader (2007), Barbiers et al. (2010), Pankau (2010) for discussion. The important point in the present context is that PPs with a potential $\mathrm{X}^{\circ}$ complement may be analyzable as syntactic heads: $\{P, N\} \Rightarrow\{P,\{P, N\}$. 
given sentences in Standard German, which they had to turn into their local dialect. The experiment was tape-recorded and transcribed. ${ }^{21}$

Table 4: Production experiment. 9 speakers from Regen (Middle to Eastern Bavarian); 10 sentences.

\begin{tabular}{lll}
\hline STANDARD GERMAN INPUT & BAVARIAN OUTPUT & PERCENTAGE \% \\
\hline model (33) & Standard German syntax & 14 \\
$\begin{array}{c}\text { e.g. [was für DP] } d u \text { VP } \\
\text { what for DP you VP }\end{array}$ & irrelevant & 9 \\
& was für split: was-st (du) für DP ... & 64 \\
& $\begin{array}{l}\text { dass-insertion: was für DP dass-st (du)... } \\
\text { XP+inflection: was für DP-st (du) ... }\end{array}$ & 15 \\
& Standard German syntax & 30 \\
\hline model (34) & dass-insertion: wie(viel)...dass-st (du)... & 70 \\
e.g. [wie(viel) & XP] du VP \\
how(much) XP you VP & XP+inflection: wie(viel)-st ... (du) & - \\
\hline
\end{tabular}

The results of this experiment could not be clearer: There was not a single case of 2nd person inflection on an XP of type [was für DP] or [wie(viel) XP]. In the first case, the leading strategy was to extract was and strand the für-XP. In this case, was could be inflected and in fact was inflected throughout. In the latter case, this strategy fails: wie cannot be extracted out of wie oft. Here we observe with $70 \%$ a clear majority of DFC with dass being inflected throughout. In both parts of the investigation, it is revealing that speakers prefer omission of the inflection, i.e. essentially a reply in Standard German, to inflection of the wh-XP. On the basis of these results, one can be sure that speakers distinguish between wh-words and wh-phrases. Wh-words pattern with externally merged complementizers in their behavior as hosts for inflection. Wh-phrases do not. These facts support the theory according to which wh-words move as C-heads and project $\mathrm{CP}$ whereas wh-phrases require external merger of a complementizer. Thus, the classical X-bar picture of DFC may be retained but must be revised for those cases in which a more economical derivation in terms of wh headmovement is viable. Again, it should be clear that a split-CP approach in which wh does not communicate with $\mathrm{C}$ at all has nothing to say about the possibility of wh-elements acting as inflected complementizers.

21 The experiment was carried out by Michael Merz in the context of his master thesis, see Merz (2011). More empirical work can be found in Bayer (2014). 
Reis (1985) noticed already that wh words attract weak pronouns and concluded that this is a problem for a theory which places the wh word in a higher position than the C-position. In an HPSG account, Kathol (2000) tries to revive the traditional linear theory of German clause structure that emerged in the late 19th century and became known as the topological fields model ("Theorie der topologischen Felder”, see Höhle (1986)). In this model, wh-phrases and C are always in the same position. ${ }^{22}$ Kathol seems to be right as far as word-size wh-operators are concerned. On the other hand, the Bavarian data on compinflection suggest that bona fide wh-phrases rely on a separately merged complementizer and therefore move beyond it.

\subsection{Consequences}

We have been able to demonstrate that word-size wh-operators show exactly the same syntactic distribution and the same morphophonological properties as externally merged complementizers and verbs in V2-position. This allows the following generalization.

(35) i. "Wackernagel-type” morphophono-logical processes - cliticization, consonantal epenthesis, comp inflection - apply uniformly to the C-position.

ii. If T-to-C movement does not apply, merge a lexical item with the categorial feature $\mathrm{C}$ to TP, no matter whether $\mathrm{C}$ is a "plain" $\mathrm{C}$ or a wh-element with a latent C-feature!

Wh head-movement relies on the C-feature which is needed to project a CP. ${ }^{23}$ The C-feature cannot be activated at a later stage in which merger with TP is no longer available. Thus, the features [ywh, ... $\beta$ Pol, $\alpha \mathrm{C}$ ] in (23) must be ordered in a feature tree that maps onto the order seen in (22) and (24). Once T-to-C movement has applied, i.e. a "V1-structure" has been created, wh cannot be merged with TP, and the prediction is that wh ends up as a specifier rather than as a head. If it is not a head, we do not expect head-typical processes such as epenthesis. Written examples can be found in which the phonological environment could give rise to $r$-epentheses but in fact does not.

22 "[there] is strong reason to believe that complementizers and wh/d-phrases in subordinate clauses belong to the same natural class in terms of their positional properties." (Kathol 2000: 111).

23 This cannot be universal, though. Notice that in Hungarian the complementizer hogy precedes wh. It must be merged after wh-movement has applied. 
(36) Wia is $-n$ des bei engk herendd, Raimund?

how is-PART this at you over-here Raimund

'Hey Raimund, how is it with you over there?'

http://www.google.de/search?q=Bairisch+\%22wia+isn $\% 22 \& b t n G=S u c h e \&$

$\mathrm{hl}=$ de\&lr=\&client=firefox-a\&rls=org.mozilla\%3Ade\%3Aofficial\&as_qdr= all\&sa $=2$

Although the wh-item is identical with the one that appears in (30) as a Celement, and although the auxiliary is would be able to undergo encliticization, $r$-epenthesis is rejected by native speakers that I have consulted with examples like (37). ${ }^{24}$

$\begin{array}{cll}{ }^{\star} \text { Wia }-\boldsymbol{r} \text {-is- } n & \text { des } & \text { bassiert? } \\ \text { how-R-is -PART } & \text { this } & \text { happened }\end{array}$

'How did this happen?'

BPS does not in principle preclude head-movement to a CP (or FinP) that is headed by the finite verb. However, empirical considerations suggest that the wh-element that has been moved in (36) and (37) counts as an XP: Elements in this position (called "Vorfeld") can be inserted for the satisfaction of the V2constraint, and they can under certain circumstances be dropped if they qualify as discourse topics. Both properties are arguably not attested with heads. We can conclude that even word-size wh-items count as XPs once they are placed before the finite verb in the sense of regular specifiers. As such, they are flanked by a strong prosodic boundary that prevents cliticization and epenthesis. ${ }^{25}$

24 The same is true for Alemannic $n$-epenthesis.

(i) ${ }^{\star} W a \quad-\boldsymbol{n}$-isch denn passiert?

what - $\mathrm{N}$-is PART happened

'What happened?'

(ii) ${ }^{\star}$ Wo $\quad$-n-isch de vater ani?

where $-\mathrm{N}$-is the father towards

'Where did father go?'

25 There is some evidence that a focused wh-word has more structure than an unfocused one. Not too surprisingly then, a focused wh-word may cooccur with a complementizer. Bayer and Brandner (2008a: 93) and Noth (1993) for more details. 


\section{A note on diachrony and variation}

It cannot be overlooked that in many languages, the unmarked complementizer corresponding to English that or German dass is an unmarked wh-pronoun of the language, corresponding to 'what'.
a. que
French, Portuguese, Spanish, Catalan
b. che
Italian
c. umo (fto) Russian
d. $c ̧ O$
Polish
e. $\tau i$ (ti)
Greek, the complementizer being ó $\tau$ (oti)
f. che
Persian ('what'), changes to the complementizer ke
g. कि (ki)
Hindi, Guajarati, Marathi, Punjabi and various other Indo-Aryan languages.

If this is not an accident, one must assume that the unmarked wh-operator has been historically reanalyzed toward a neutral, i.e. non-interrogative, complementizer. From research on grammaticalization, the featural impoverishment (alias "bleaching") of affected elements is a familiar process. ${ }^{26}$ It is interesting to see in this context that even in Germanic varieties examples can be found in which a wh-word serves either as a polar complementizer or as a non-interrogative ("declarative") complementizer altogether. (39) is from a Low German dialect reported in Zimmermann (2011). (40) is from Yiddish, reported by Kühnert \& Wagner (2004), and (41) is from Bernese Swiss German, reported by Hodler (1969) and Penner (1993).

26 An alternative analysis interprets the homophony of wh-operator and complementizer as identity and argues that complements are actually relative clauses. Kayne (to appear) says "the that that introduces sentential complements is really a relative pronoun, and sentential complements are really relative clauses, in a way that partially recalls Rosenbaum (1967)”. For more discussion of this proposal, which I cannot evaluate here, see Arsenijevic (2009); Manzini (2012); Manzini and Savoia (2003). The proposal leaves many questions open, for instance why German has overwhelmingly a d-word and not a w-word as complementizers although free relatives are as in (i) and not as in (ii).

(i) Was du behauptest ist falsch

what you claim is wrong

(ii) ${ }^{\star}$ Das du behauptest ist falsch

Another question is why Scandinavian uses a preposition (att) as a complementizer, an element that seems to be an odd candidate for a relativizer. 
(39) LOW GERMAN

Ik weet nich wat de Bodder al smolten is

I know not WAT the butter already melted is

'I don't know if the butter has melted already'

http://www.plattpartu.de/kuenst/lueske1_biller.htm; 12.02.07

(40) YIDDISH

veyśtu den nit voz unz Ari zu gihert

know-you PRT not what us Ari to belongs

'Don't you know that Ari belongs to us?'

(41) BERNESE SWISS GERMAN

I gloub nid \{wo / wa / was $\}$ er chunt

I believe not where / what / what he comes

'I don't believe that he will come'

It looks as if there is a grammaticalization path which runs as in (42).

(42) Grammaticalization path for wh with increasing featural impoverishment ${ }^{27}$ + wh phrase $>+$ wh head $>$ polar interrogative head $>-$ wh head

$$
\left[\begin{array}{c}
+ \text { wh } \\
+ \text { pol } \\
+ \text { res }
\end{array}\right] \quad\left[\begin{array}{c}
+ \text { wh } \\
+ \text { pol } \\
- \text { res }
\end{array}\right] \quad\left[\begin{array}{l}
-\mathrm{wh} \\
+ \text { pol } \\
- \text { res }
\end{array}\right] \quad\left[\begin{array}{l}
- \text { wh } \\
- \text { pol } \\
- \text { res }
\end{array}\right]
$$

This path maps onto the three layers of the split CP that have been attested in Dutch, see (22) above, and which we could find again in terms of feature structure in Bavarian, see (23) and (24) above. The categorial feature $C$ that was previously introduced as a primitive may turn out not to be primitive but rather the consequence of featural impoverishment that leads to a wh-lexeme which actually lacks the semantic part of the wh-feature and is as a consequence recruited as a complementizer. ${ }^{28}$

The present account also finds a straight explanation why semantically restricted wh-words do not turn into pure subordinators. ${ }^{29} \mathrm{~A}$ form like ${ }^{\star} I$ believe when you are depressed can presumably not stand in any language for the meaning I believe that you are depressed. This is so because the semantic restriction,

27 "res" stands for a semantic restriction that appears automatically in a phrase.

28 This squares with the widely known fact that complementizer (C) is a highly inhomogeneous category which embraces at least d-pronouns, wh-pronouns, prepositions and verbs.

29 Thanks to Richie Kayne (p.c.) for drawing my attention to this fact. 
in this example TIME, would in all likelihood resist neutralization. This does not mean though that a wh-word like German wann ('when') could not synchronically act as a complementizer and as an operator. The important fact is that it has a sub-structure which it can discharge upon an internal merge operation, and which the syntax can identify as the activation of a subordinative function. This is what we mean by a "C-feature" or a "latent C-feature". From the viewpoint of diachrony and grammaticalization, the question is different. Here the question is how it can be that a wh-operator changes as a whole into a complementizer. Given what is known about the extreme underspecification of correspondents of "what", there is no doubt that this element stands a high chance of being recruited as a pure subordinator. ${ }^{30}$

To draw a conclusion from this brief digression into diachrony and variation, the proposed account of wh-movement as economy-driven head-style movement seems to be highly susceptible to a more general theory which integrates syntactic development across time and syntactic variation.

In the last two sections, I will very briefly turn to two potential problems for the analysis proposed above.

\section{Sluicing}

Baltin (2010) argues that DFC does not exist at all, the reason being that it supposed to make wrong predictions about sluicing. Sluicing (Ross 1967) has been studied in detail in Merchant $(2000,2006)$ and is standardly described as a deletion operation that spares the wh-phrase as seen in (43b).

\section{(43) a. Fred gave someone my keys but I can't remember when \\ b. Fred gave someone my keys but I can't remember when he gave this person my keys}

At first sight, sluicing seems to be straightforwardly accounted for by TPdeletion. Assuming now that in DFC-languages the wh-operator moves to the specifier of an overt complementizer, the remnant after TP-deletion would be wh plus comp. It is, however, known at least since Lobeck (1995) that sluicing does not spare comp.

30 A rich source of evidence can be found in Jäger (2000). 
(44) Hans hat von jemandem Geld gekriegt, aber ich habe Hans has from someone money gotten but I have vergessen von wem ( ${ }^{*}$ dass)

forgotten from who (that)

'Hans got money from someone but I've forgotten from who'

The proposal to have sluicing target C' instead of TP is ad hoc and X-bar theoretically unattractive as it affects an intermediate projection. Following Rizzi's (1997) split CP analysis, Baltin argues that wh and comp are in fact never in the same CP. In this case, one can assume that sluicing targets the lower CP-shell which contains comp but spares the higher CP-shell that contains the wh-operator. ${ }^{31}$
a. $\left[{ }_{C P 2} w h\left[_{C 2}, \emptyset\left[{ }_{C P 1} \emptyset\left[{ }_{C 1}\right.\right.\right.\right.$, dass $\left.\left.\left.\left.\left[{ }_{T P} \ldots w h \ldots\right]\right]\right]\right]\right]$ CP1-deletion $\Rightarrow$
b. $\left[{ }_{C P 2} w h\left[{ }_{C 2}, \emptyset \mathrm{t}_{\epsilon P 1} \emptyset\left[\left[_{\epsilon 1}, \operatorname{dass}\left[{ }_{T P} \ldots w h \ldots\right]\right]\right]\right.\right.$

As we have pointed out already in 5.1, this cartographic account can hardly propose more about the interaction of wh and comp than some spell-out convention. The Bavarian data which had been presented so far, however, have shown that wh and comp interact heavily: Word-size wh-operators compete with comp while wh-phrases do not. Word-size wh and comp but not phrasal wh is the target for cliticization and epenthesis. Word-size wh and comp bear 2nd person inflection whereas phrasal wh does not. On the other hand, Bavarian word-size wh-operators behave fully regularly under sluicing. Consider (46a,b).

\section{a. D'Resl woidd kumma owa $i$ woass ned wann the-Therese wanted come but I know not when 'Therese wanted to come but I don't know when'}

b. Da Hias mechat sei Moped frisian owa er woass ned wia the Matthias wants his moped improve but he knows not how 'Matthias wants to increase the power of his moped but he does not know how'

Although wh-items such as wann or wia behave like $\mathrm{C}$ (due to their latent C-feature), sluicing does not target them. If it did, unrecoverable information would be lost, and the prediction would be that sluicing does not exist in this dialect to begin with. It is easy to see that the present account does not yield

31 Baltin proposes the deletion of FinP, which in Rizzi (1997) would correspond the lower projection which I call here CP1 for reasons of simplicity. 
such a conclusion. Conditioned by the feature bundling seen in (23), a word-size wh-item moves as shown in (24). It is first remerged with TP activating the latent C-feature. This leads to the projection of what we have called CP1 in (45). Thanks to the purely interrogative feature Pol, it is then remerged a second time giving rise to PolP, i.e. quasi another "CP-shell". Due to its wh-feature, the wh-item will undergo internal merger a third time. This last step leads to the activation of the wh-property and to the projection of a WhP, which corresponds to yet another CP-shell. Sluicing can target the CP-shell immediately dominated by WhP. As such, there is no reason to believe that wh head-movement would face more problems than any other account with respect to sluicing.

What about wh-phrases then? Baltin's worry is that TP-deletion wrongly predicts that the complementizer survives. CP-deletion, on the other hand, would also erase the wh-phrase. Notice, however, that under the assumptions of BPS, there is no predetermined difference between C' and CP. Therefore, it is not possible to express a restriction against the deletion of an intermediate projection. As soon as dass or an empty complementizer is merged with TP, a CP results. This fact is independent of further attachments which may take the role of a specifier. The important fact is that dass heads a CP. If sluicing wants to get rid of the (informationally irrelevant) complementizer dass, it can do so. ${ }^{32}$

To conclude, Baltin's argument against previous accounts of DFC is essentially valid but the cure that he offers in terms of an X-bar based cartographic split CP fails to accommodate central Bavarian data, namely those that point to a competition between complementizers and comp-like wh-items. In the present account, instead, comp-like wh-items have a latent C-feature by which they are remerged as heads. If we assume in an extension of Bayer and Brandner (2008a, b) that the simplex wh-item activates different CP-shells of which the wh-feature is activated in the highest one, sluicing as CP-shell deletion as suggested by Baltin does not present a problem at all.

32 What I am saying here should by no means be misunderstood as my account of sluicing; I don't have any. If I have understood Merchant (2006) correctly, sluicing remains a partially unresolved construction. Why does it allow multiple wh-phrases in languages which otherwise, unlike Slavonic, allow only a single wh-phrase in SpecCP? Why should island violations as they arise under sluicing be "repaired" by deletion? Why does Hungarian retain the complementizer hogy under sluicing as in Merchant's (2006) example (i), but only optionally so as Krisztá Szendröi (p.c.) points out to me?

(i) A gyerekek találkoztak valakivel de nem emlékszem, (hogy) kivel. the children met someone-with but not I-remember that who-with 'The kids met with someone, but I don't remember with who'

As long as these problems - and this is only a selection - can only be addressed with special assumptions, arguments from sluicing against the very existence of the DFC-phenomenon such as those forwarded by Baltin should, in my view, be met with reservation. 


\section{A note on chain uniformity}

As far as BPS is understood at this moment, a wh-element that is merged with a head is declared an XP, and so is a wh-element that is adjoined to some phrase. The Condition on Chain Uniformity (CCU) as formulated in (47) requires the chain links of a wh-chain to be of type XP.

(47) Condition on Chain Uniformity

A chain must be uniform, where a given chain $C=\left(\alpha_{1}, \ldots, \alpha_{n}\right)$ is uniform with respect to $\mathrm{P}$ if each $\alpha_{i}$ has property $\mathrm{P}$.

(Chomsky and Lasnik 1993; taken from Chomsky 1995: 91)

Wh head-movement as proposed in this study violates the CCU. The problem may be new with respect to wh-movement. However, it is not new with respect to other types of movement. Relevant discussion of the CCU was devoted in the past to clitic movement. A clitic with argument status, say an object clitic, is merged with $\mathrm{V}$ and should therefore be relationally defined as an XP. At its landing site, the clitic should, however, have $\mathrm{X}^{\circ}$ qualities. It adjoins to a functional head. The most elementary question is then how an $\mathrm{X}^{\circ}$ can bind an XP. Another question is how an $\mathrm{X}^{\circ}$ can bind XP if - as in the present case of wh-Cprojection $-\mathrm{X}^{\circ}$ has to project? According to standard assumptions, the target does not project. The situation is summarized in (48).

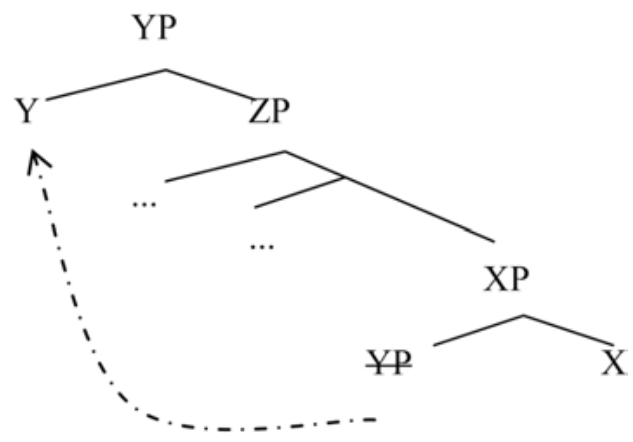

Referring to clitics, Chomsky (1995: 403) says that they "appear to share XP and $\mathrm{X}^{\circ}$ properties, as we would expect on minimalist assumptions". In other words, the projective status of the moving element is ambiguous. What Chomsky 
says pertains to wh head-movement more than to clitic movement. ${ }^{33}$ All of the wh-words we have been talking about can wind up in the C-position as well as in the SpecCP position. In the latter case, there is no sign of a head property. As a consequence, word-size wh-operators must be X-bar theoretically ambiguous between XP and $\mathrm{X}^{\circ}$ status. Adopting BPS as well as head-raising and reprojection (Münchhausen style head movement), Bayer and Brandner (2008a) suggest the following relaxation of the CCU.

(49) Condition on Chain Uniformity (as in (47) above) (revised) The chains $\mathrm{CH}=\left(\mathrm{X}^{\circ} \ldots \mathrm{XP}\right)$ and $\mathrm{CH}=\left(\mathrm{XP} \ldots \mathrm{X}^{\circ}\right)$ are uniform iff $\mathrm{X}^{\circ}$ is surface-equivalent with $\mathrm{XP}$, and $\mathrm{XP}$ is surface-equivalent with $\mathrm{X}^{\circ} .{ }^{34}$

The local requirements of the chain links are met. Upon merger with $\mathrm{V}$, a whpronoun will be definable as a DP; upon remerger with TP it will be definable as a potential C-head. Beyond that, $\mathrm{X}^{\circ}$ can be an antecedent of XP in the sense that $\mathrm{X}^{\circ}$ is formally indistinguishable from XP, and XP can be an antecedent of $\mathrm{X}^{\circ}$ in the sense that XP is formally indistinguishable from $\mathrm{X}^{\circ} .{ }^{35}$

Given that head movement as such has been a tremendous and also tremendously controversial topic in recent work in minimalist syntax, these brief remarks cannot be more than a suggestion in which way to defend the claim that has been made here, namely that word-size wh-items may be internally merged like C-heads and may then autonomously project their own CP. Whatever the best technical implementation of head movement is, in terms of the Minimalist Program this account seems to me preferable over the minimalist standard account by which a zero phantom complementizer with an unvalued wh-feature has to be merged to TP before a wh-phrase with an interpretable wh-feature can move to its specifier. The observed restrictions on DFC and the morphophonological restrictions in the syntax of Bavarian strongly support economical derivations in which the decisive criterion is the maximization of internal merger.

33 Clitics are phonologically highly special elements whereas the shape of the wh-operators we are talking about remains lexically pretty much the same across environments.

34 By "surface-equivalence" I mean shape identity as it occurs time and again in language, for instance in the German Case system where we find der Frau as a "portmanteau" for genitive singular and dative singular. One can show that a single representative of such a constituent can associate with more than a single grammatical function.

35 See the discussion of chain uniformity in Roberts (2010: 31-33), where it is pointed out that rigid chain uniformity dissolves in the sense of our (49) because the notion of "chain" loses its status as a primitive in a strictly derivational theory. 


\section{Conclusion}

Following the lead of the Minimalist Program, especially the lead of BPS and projective economy, a more fine-grained analysis of the Doubly-Filled Comp (DFC) phenomenon was achieved. The empirical results, based on a number of judgment and production tests, show that DFC in Bavarian is not as pervasive as previously assumed. It is notably absent with the pronoun was and heavily reduced with other simplex wh-words. The results show furthermore that cliticization, consonantal epenthesis and comp-inflection apply uniformly to both complementizers and short wh-elements, suggesting that wh and comp are members of a natural class in terms of their role in the syntax of embedded clauses. Previous X-bar theoretic accounts but also more recent ones which assume an invariable mapping of wh and comp to fixed phrase structural positions can hardly capture these restrictions. This was obviously the reason why traditional ideas about the linear organization of grammar were taken up again in HPSG. The derivational sub-theory of clause structure which was presented here is based on a natural and in fact independently motivated assumption, namely that the feature matrix of wh-words involves a latent comp-feature. This feature gets activated in the course of the derivation as soon as the wh-word is internally merged with TP. Since wh and comp fall together in a single lexical item, external merger of a separate comp, let alone a zero comp, is superfluous and is therefore ruled out by derivational economy. DFC, which is otherwise pervasive in Bavarian, is suspended in these cases. The permission of head-style wh-movement in syntax predicts a close fit with the PF-side. Post-syntactic morphophonological processes which typically apply to functional heads can do so directly, i.e. without having to cope with categorial mismatches, zero elements or non-contiguity.

\section{Acknowledgments}

Central parts of this article rest on work with Ellen Brandner, see Bayer \& Brandner (2008a,b) I wish to thank Michael Merz for the collection of data on compinflection and Annika Nitschke for editorial work. For discussion special thanks to Ellen Brandner, Joe Emonds, Günther Grewendorf, Alex Grosu, Hilda Koopman, Antje Lahne, Rita Manzini, Luigi Rizzi, Manuela Schönenberger, Øystein Vangsnes, Helmut Weiß and Marit Westergaard. Special thanks to an anonymous reviewer whose comments have improved this paper. The responsibility for any errors is exclusively on my side. 


\section{References}

Altmann, Hans. 1984. Das System der enklitischen Personalpronomina in einer mittbairischen Mundart. Zeitschrift für Dialektologie und Linguistik 51 (2): 191-211.

Arsenijevic, Boban. 2009. Clausal complementation as relativization. Lingua 119: 39-50.

Baltin, Mark. 2010. The nonreality of doubly filled comps. Linguistic Inquiry 41: 331-335.

Baker, Carl L. 1970. Notes on the description of English questions: the role of an abstract question morpheme. Foundations of Language 6: 197-219.

Barbiers, Sjef, Hans Bennis, Gunther De Vogelaer, Magda Devos, and Margreet van der Ham (eds.). 2005. Syntactic Atlas of the Dutch Dialects. Vol. 1. Amsterdam: Amsterdam University Press.

Barbiers, Sjef, Olaf Koeneman, and Marika Lekakou. 2010. Syntactic doubling and the structure of wh-chains. Journal of Linguistics 46 (1): 1-46.

Bayer, Josef. 2014. Syntactic and phonological properties of wh-operators and wh-movement in Bavarian. In Bavarian Syntax, Günther Grewendorf, and Helmut Weiß (eds.), 23-50. Amsterdam: Benjamins.

Bayer, Josef. 2004. Decomposing the left periphery - dialectal and cross-linguistic evidence. In The syntax and Semantics of the Left Periphery, Horst Lohnstein, and Susanne Trissler (eds.), 59-95. Berlin: de Gruyter.

Bayer, Josef. 1984. COMP in Bavarian syntax. The Linguistic Review 3: 209-274.

Bayer, Josef, and Markus Bader. 2007. On the syntax of prepositional phrases. In Interface and Interface Condtions, Andreas Späth (ed.), 157-179. Berlin: de Gruyter.

Bayer, Josef, Markus Bader, and Michael Meng. 2001. Morphological underspecification meets oblique case: Syntactic and processing effects in German. Lingua 111: 465-514.

Bayer, Josef, and Eleonore Brandner. 2008a. On wh-head-movement and the doubly-filledcomp filter. In Proceedings of the 26th West Coast Conference on Formal Linguistics, Charles B. Chang, and Hannah J. Haynie (eds.), 87-95. Somerville: Cascadilla Proceedings Project.

Bayer, Josef, and Eleonore Brandner. 2008b. Wie oberflächlich ist die syntaktische Variation zwischen Dialekten? - Doubly-filled COMP revisited. In Dialektale Morphologie, dialektale Syntax, Franz Patocka, and Guido Seiler (eds.), 9-26. Vienna: Praesens.

Bittner, Maria, and Ken Hale. 1996. The structural determination of case and agreement. Linguistic Inquiry 27 (1): 1-68.

Borer, Hagit. 1984. Parametric Syntax: Case Studies in Semitic and Romance Languages. Dordrecht: Foris.

Brandner, Eleonore. 2004. Head-movement in minimalism and V2 as force-marking. In The syntax and semantics of the Left Periphery, Horst Lohnstein, and Susanne Trissler (eds.), 97-138. Berlin: de Gruyter.

Cardinaletti, Anna. 1999. Pronouns in Germanic and Romance languages: an overview. In Clitics in the Languages of Europe, Henk C. van Riemsdijk (ed.), 33-81. Berlin: de Gruyter.

Chomsky, Noam. 2010. Restricting stipulations: consequences and challenges. Lecture. University of Stuttgart. 24 March, 2010. de/upload_data_www/534/3637/aufzeichnung.flv? 124,234

Chomsky, Noam. 2001. Derivation by phase. In Ken Hale: A Life in Language, M. Kenstowicz (ed.), 1-52. Cambridge/MA: MIT Press. 
Chomsky, Noam. 1995a. Bare phrase structure. In Government and Binding Theory and the Minimalist Program, Gert Webelhuth (ed.), 383-439. Oxford: Blackwell.

Chomsky, Noam. 1995b. The Minimalist Program. Cambridge, MA: MIT Press.

Chomsky, Noam, and Howard Lasnik. 1977. Filters and control. Linguistic Inquiry 8: 425-504.

van Craenenbroeck, Jeroen. 2006. Transitivity failures in the left periphery and foot-driven movement operations. Linguistics in the Netherlands 23: 52-64.

Donati, Caterina. 2006. On wh-head movement. In Wh-movement: Moving on, Lisa Cheng, and Nobert Corver (eds.), 21-46. Cambridge/MA: MIT Press.

Fanselow, Gisbert. 2004. Münchhausen-style head movement and the analysis of verb second. In Linguistics in Potsdam 22, [Ralf Vogel (ed.), Three Papers on German Verb Movement]: 9-49.

Fuß, Eric. 2005. The Rise of Agreement. A Formal Approach on the Syntax and Grammaticalization of Verbal Inflection. Amsterdam: Benjamins.

Gelderen, Elly van. 2004. Grammaticalization as Economy. Amsterdam: Benjamins.

Georgi, Doreen, and Gereon Müller. 2010. Noun-phrase Structure by reprojection. Syntax 13:136.

Gorrell, Paul. Structural relations in the grammar and the parser. Special issue of Folia Linguistica 28 (1-2). Josef Bayer (ed.), 1995. Syntax and parsing. Cambridge: Cambridge University Press.

Groenendijk, Jeroen, and Martin Stokhof. 1982. Semantic analysis of wh-complements. Linguistics and Philosophy 5: 175-233.

Gutch, Donald. 1992. Linking and intrusive $r$ in English and Bavarian. In Language and Civilization: A Concerted Profusion of Essays and Studies in Honor of Otto Hietsch. Vol. 1. Claudia Blank (ed.), 555-611. Frankfurt a. Main: Lang.

Haan, Germen de, and Fred Weerman. 1986. Finiteness and verb fronting in Frisian. In Verb Second Phenomena in Germanic Languages, Hubert Haider, and Martin. Prinzhorn (eds.), 77-110. Dordrecht: Foris.

Haegeman, Liliane. 1992. Theory and Description in Generative Syntax: A Case Study in West Flemish. Cambridge: Cambridge University Press.

Higginbotham, James. 1997. The semantics of questions. In The Handbook of Contemporary Semantic Theory, Shalom Lappin (ed.), 361-383. Oxford: Blackwell.

Higginbotham, James. 1993. Interrogatives. In The View from Building 20, Kenneth Hale, and Samuel J. Keyser (eds.), 195-228. Cambridge MA: MIT-Press.

Hodler, Werner. 1969. Berndeutsche Syntax. Bern: Francke.

Höhle, Tilman. 1986. Der Begriff “Mittelfeld”. Anmerkungen über die Theorie der topologischen Felder. In Akten des Siebten Internationalen Germanistenkongresses 1985, Göttingen, Germany, Albrecht Schöne (ed.), 329-340. Tübingen: Niemeyer.

Hoekstra, Eric. 1993. Dialectal variation inside CP as parametric variation. In Dialektsyntax, Werner Abraham, and Josef Bayer (eds.), 161-179. (Special issue \#5 of Linguistische Berichte) Opladen: Westdeutscher Verlag.

Jäger, Agnes. 2000. Unterspezifikation am Beispiel des Pronomens was. Zur Grammatik eines $w$-Elements. MA thesis, Friedrich Schiller Universität Jena.

Kathol, Andreas. 2000. Linear Syntax. Oxford: Oxford University Press.

Kayne, Richard S. 2010. Why isn't this a complementizer?. In Comparison and Contrasts, Richard S. Kayne (ed.), 190-227. Oxford: Oxford University Press.

Koeneman, Olaf. 2002. The distribution of declarative verb second in Germanic. In Studies in Comparative Germanic Syntax, Jan-Wouter Zwart, and Werner Abraham (eds.), 175-201. Amsterdam: Benjamins. 
Koeneman, Olaf. 2000. The Flexible Nature of Verb Movement. Utrecht: LOT Publications. Koopman, Hilda. 2000. The Syntax of Specifiers and Heads. London: Routledge.

Kühnert, Henrike, and Esther-Miriam Wagner. 2004. Konnektive in der diachronen Entwicklung des Jiddischen. In Indogermanistik - Germanistik - Linguistik, Maria Kozianka, Rosemarie Lühr, and Susanne Zeilfelder (eds.), 261-299. Hamburg: Dr. Kovac.

Lahiri, Utpal. 2002. Questions and Answers in Embedded Contexts. Oxford: Oxford University Press.

Lobeck, Anne. 1995. Ellipsis. Oxford: Oxford University Press.

Manzini, Maria Rita. 2012. The status of complementizers in the left periphery. In Main Clause Phenomena. New Horizons, Lobke Aelbrecht, Liliane Haegeman, and Rachel Nye (eds.), 297-318. Amsterdam: Benjamins.

Manzini, Maria Rita, and Leonardo Savoia. 2003. The nature of complementizers. Rivista di grammatica generative 28: 87-110.

Merchant, Jason. 2001. The Syntax of Silence. Oxford: Oxford University Press.

Merchant, Jason. 2006. Sluicing. In The Syntax Companion, Martin Everaert, and Henk van Riemsdijk (eds.), 269-289. London: Blackwell.

Merkle, Ludwig. 1984. Reprint. Bairische Grammatik. 2nd ed. München: Hugendubel. Original edition, München: Heimeran Verlag, 1975.

Merz, Michael. 2011. Die [r]-Epenthese im Bairischen - zwischen Phonologie und Syntax. MA thesis, University of Konstanz.

Müller, Gereon. 2004. Verb-second as vP-first. Journal of Comparative Germanic Linguistics 7: 179-234.

Noth, Harald. 1993. Alemannisches Dialekthandbuch vom Kaiserstuhl und seiner Umgebung. Freiburg im Breisgau: Schillinger.

Ortmann, Albert. 1998. Consonant epenthesis: Its distribution and phonological specification. In Phonology and Morphology of the Germanic Languages, Wolfgang Kehrein, and Richard Wiese (eds.), 51-76. Tübingen: Niemeyer.

Pankau, Andreas. 2010. Wh-Copying in German and its Theoretical Implications, University of Frankfurt \& University of Utrecht. Handout.

Penner, Zvi. 1993. W-morphology in the COMP system of Bernese Swiss German and the licensing of empty operators in the prefield position. In Dialektsyntax, Werner Abraham, and Josef Bayer (eds.), 201-212. (Special issue \# 5 of Linguistische Berichte) Opladen: Westdeutscher Verlag.

Penner, Zvi and Thomas Bader. 1995. Issues in the syntax of subordination: A comparative study of the complementizer system in Germanic, Romance, and Semitic languages with special reference to Bernese Swiss German. In Topics in Swiss German Syntax, Zvi Penner (ed.) 73-289. Bern.

Pesetsky, David, and Esther Torrego. 2001. T-to-C movement: Causes and consequences. In Ken Hale: A Life in Language, Michael Kenstowicz (ed.), 355-426. Cambridge MA: MIT Press.

Pfalz, Anton. 1918. Suffigierung der Personalpronomina im Donaubairischen' Kaiserliche Akademie der Wissenschaften in Wien, philosophisch-historische Klasse, Sitzungsberichte 190.

Platzack, Christer. 1996. Germanic verb second - attract versus repel: On optionality, A-bar movement and the symmetrical/asymmetrical verb second hypothesis. In Deutsch typologisch, Ewald Lang, and Gisela Zifonoun (eds.), 92-120. Berlin: de Gruyter.

Reis, Marga. 1985. Satzeinleitende Strukturen im Deutschen. Über COMP, Haupt - und Nebensätze, w-Bewegung und die Doppelkopfanalyse. In Erklärende Syntax des Deutschen, Werner Abraham (ed.), 271-311. Tübingen: Narr. 
Reuland, Eric. 1990. Head movement and the relation between morphology and syntax. In Yearbook of Morphology 3, Geert Booij, and Jaap van Marle (eds.), 129-161. Dordrecht: Foris.

Rizzi, Luigi. 1997. The fine structure of the left periphery. In Elements of Grammar, Liliane Haegeman (ed.), 281-337. Dordrecht: Kluwer.

Roberts, Ian. 2010. Agreement and Head Movement. Cambridge MA: MIT Press.

Rosenbaum, Peter. 1967. The Grammar of English Predicate Complement Constructions. Cambridge MA: MIT Press.

Ross, John R. 1969. Guess who?. In Papers from the Fifth Regional Meeting of the Chicago Linguistic Society (CLS), Robert I. Binnick, Alice Davison, Georgia M. Green, and Jerry L. Morgan (eds.), 252-286. Montreal: Montreal Working Papers in Linguistics.

Schiepek, Josef. 1899. Der Satzbau der Egerländer Mundart. Prag: Verlag des Vereines für Geschichte der Deutschen in Böhmen.

Schönenberger, Manuela. 2006. A glimpse of doubly-filled COMPs in Swiss German. In Organizing Grammar: Studies in Honor of Henk van Riemsdijk, Hans Broekhuis, Norbert Corver, Riny Huybregts, Ursula Kleinhenz, and Jan Koster (eds.), 572-581. Berlin: de Gruyter.

Seiler, Guido. 2003. Präpositionale Dativmarkierung im Oberdeutschen. Stuttgart: Steiner.

Starke, Michal. 2009. Nanosyntax. A short primer to a new approach to language. Nord-lyd 36 (1): 1-6. Special issue on Nanosyntax, ed. Peter Svenonius, Gillian Ramchand, Michal Starke, and Knut Tarald Taraldsen, pp. 1-6. CASTL, Tromsø. http://www.ub.uit.no/baser/ nordlyd/

Steininger, Reinhold. 1994. Beiträge zu einer Grammatik des Bairischen. Stuttgart: Steiner.

Sternefeld, Wolfgang. 1997. Comparing Reference Sets. In The Role of Economy Principles in Linguistic Theory, eds. Chris Wilder, Hans-Martin Gärtner and Manfred Bierwisch, 81-114. Berlin: Akademie Verlag.

Surány, Balázs. 2003. Head movement and reprojection. Annales Universitatis Scientiarum Budapestinensis de Rolando Eötvös Nominatae. Sectio Linguistica. Tomus XXVI: 313-342. Budapest: ELTE.

Vangsnes, Øystein A. 2005. Microparameters for Norwegian wh-grammars. Linguistic Variation Yearbook 5: 187-226.

Weiß, Helmut. 2005. Inflected complementizers in continental West Germanic dialects. Zeitschrift für Dialektologie und Linguistik 72: 148-166.

Weiß, Helmut. 2004. Vom Nutzen der Dialektsyntax. In Morphologie und Syntax deutscher Dialekte und historische Dialektologie des Deutschen. Beiträge zum 1. Kongress der Internationalen Gesellschaft für Dialektologie des Deutschen, Marburg/Lahn, 5.-8. März 2003, eds. Franz Patocka and Peter Wiesinger, 21-41. Vienna: Praesens.

Weiß, Helmut. 1998. Die Syntax des Bairischen. Studien zur Grammatik einer natürlichen Sprache. Tübingen: Niemeyer.

Westergaard, Marit R., and Øystein Vangsnes. 2005. Wh-questions, V2, and the left periphery of three Norwegian dialect types. Journal of Comparative Germanic Linguistics 8 (1-2): 119-160.

Wiese, Richard. 1996. The Phonology of German. Oxford: Oxford University Press.

Zimmermann, Malte. 2011. Quantificational structures in low German: On the functional structure of DP and the feature content of pronominal quantifiers. Journal of Comparative Germanic Syntax 14 (3): 203-240. 
